\title{
$\begin{array}{ll}\text { Research Square } & \text { Preprints are preliminary reports that have not undergone peer review. } \\ \text { They should not be considered conclusive, used to inform clinical practice, } \\ \text { or referenced by the media as validated information }\end{array}$
}

\section{Child Injury Burden and Risk Profile in a Bangladeshi Rural Community: an Age-Group Related Overview}

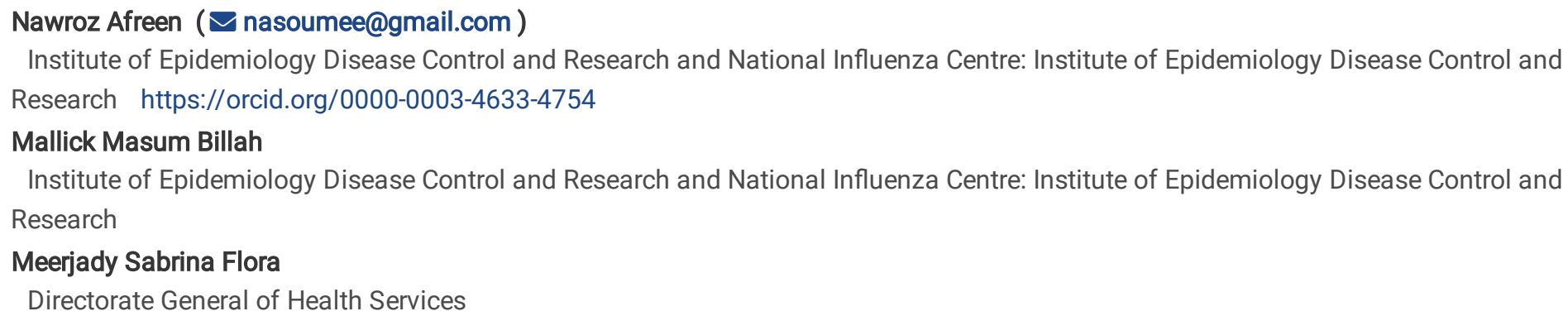

\section{Original Contribution}

Keywords: child injury, age-group, injury-severity, risk-profile, Bangladesh

Posted Date: June 16th, 2021

DOI: https://doi.org/10.21203/rs.3.rs-611568/v1

License: (a) (i) This work is licensed under a Creative Commons Attribution 4.0 International License. Read Full License 


\section{Abstract}

\section{Background:}

Child injury was a growing public health problem in Bangladesh. Recent information on variation in patterns of non-fatal injury, severity, and risk-profile in rural Bangladeshi children was unavailable. This study aimed to determine current burden of non-fatal injury and risks considering severity in disability-days in child age-groups in a rural community.

\section{Methods:}

This cross-sectional study was conducted in randomly chosen children (<18-year) from selected households of village-clusters with pretested semi-structured questionnaires and checklist for household-environment between May-June 2018 in selected sub-district. Besides descriptive analysis, Chi-square test and Odds Ratio with 95\% Confidence Interval (Cl) were calculated for identifying risk profiles. An injury was considered minor when regular activities were hampered $<30$ days and major when $\geq 30$ days. A minor injury must have occurred in the previous three months and a major injury in previous year.

\section{Results:}

For 918 children, prevalence of major and minor injury were 2.4 (95\% Cl 1.5-3.6) and 7.4 (95\% Cl 5.8-9.3) with highest in 5-9 and 1-4-year respectively. Commonest pattern was fall injury, followed by cut injury, transport injury and burn for both major and minor type, with variations in age-groups. For major-injury, risks included male gender (OR 4.6, 95\% Cl 1.5-18.9), dumped garbage (OR 5.0, 95\% Cl 1.5-26.7), and exclusive/complementary use of non-electric power-source (OR $5,95 \% \mathrm{Cl} 1.2-16.1)$. For minor-injury, risks for all age groups were $\geq 5$ working hours/day of a mother (OR 2.8, 95\% $\mathrm{Cl} 1.2-7.2)$, supervision of $<6$ children during her works (OR $3.2,95 \% \mathrm{Cl} 1.05-13)$ and open fireplaces (OR $3.2,95 \% \mathrm{Cl}$ 1.3-7.2). When analysis of minor injury considering specific age-groups was done, mothers' $\geq 5$ working hours and child-supervision were particularly found risky for 1-4 year; open fireplaces for 5-9 year; along with male gender, uneducated mothers for 10-14 year.

\section{Conclusions:}

Prevalence of major and minor injuries were though lower, still required intervention for further reduction and the variabilities in burden, patterns, severity and risks among age-groups could be considered for prioritizing interventions. As risk characteristics were not well established in a cross-sectional study, further case-control study with a qualitative part was recommended for assimilation of risk-profile to guide policy formulation.

\section{Introduction}

Injuries are a global public health problem claiming more than 14,000 deaths a day, more than five million a year, and 1.7 times of total deaths from HIV/AIDS, TB, and malaria. ${ }^{(1)}$ Deaths remain at top of the injury-pyramid outcome with hospitalizations, emergency visits, doctor's appointments, and non-treatment seeking injuries gradually forming a wider base. ${ }^{(2)}$ In 2013, globally, 973 million people sought medical care for an injury resulting in disability-adjusted life years (DALYs), years of life lost (YLLs) and years lived with disability (YLDs) of 247.6 million, 210.8 million, 36.8 million respectively; whereas death was around 4.8 million (UI 4.5 to 5.1 ). ${ }^{(3)}$

Child injury, though neglected for years ${ }^{(4)}$, now requires attention. Around 950,000 child deaths ( $<18$ years) are attributed to injury and violence throughout the world each year ${ }^{(4)}$; in 2012, among children of 5-14 years age group, 83,604 children died due to road traffic accidents, 74,712 from drowning and 41,575 from fire related burns. ${ }^{(1)}$ The rate of child death is five times higher in low and middleincome countries than in high-income countries. ${ }^{(5,6)}$ Injuries also differ between social classes within the country, and between rural and urban settings. A higher risk of injuries being found in a rural community than urban. ${ }^{(7-12)}$ Many demographic and socio-economic factors (e.g., age and sex of the child; age, education and occupation of mothers, outdoor working mothers, family type, family income, adult

supervision) make children more prone to injury than adults. ${ }^{(13-18)}$ Exposure to readily available environmental hazards e.g. crowded living without enough space for safe play, lack of separated kitchens along with the presence of open fire; unsafe houses unguarded windows, roofs, stairs; open water containers, easy access to poisonous substances and pesticides and medicines due to unsafe packaging and storage, nearby heavy traffic put poor children at risk of injury. $(4,19,20)$

In Bangladesh, injury mortality is the least in infants (3.2\%) among all child age groups (<18 years). The mortality increases with age, as for $52.6 \%$ for $1-4-y e a r, 42.1 \%$ for $5-9$-year, $56.9 \%$ for $10-14$-year, and $60.7 \%$ for $15-17$-year age groups. Drowning $(25.7 / 100,000)$ and 
suicides $(16.8 / 100,000)$ are identified as two leading causes of fatal injuries in children. As for morbidity in all age groups, the 5-9-year age group of children was the second-highest to suffer morbidity $(13,442.5 / 100,000)$ and fall injury was the most common pattern. ${ }^{(21)}$ In Bangladesh $72 \%$ of the total population live in rural areas; most of the children grow up in an environment, which exposes them to most of the above-mentioned risks along with lack of preventive services, general knowledge in first aid, and access to emergency medical care. ${ }^{(22)}$ These rural children are more prone to injury than urban children. Besides, patterns of injuries, severity, and risk profile vary much with different age groups in childhood, though information regarding Bangladeshi children, particularly rural, was not readily available after the last nationwide survey in 2005, which, however, did not include variation in risk profile with an age difference. (22) Considering all the above facts, this study aimed to estimate the child injury burden and risk profile in a Bangladeshi rural community focusing on agegroups along with consideration of injury severity in disability days.

\section{Materials And Methods}

This cross-sectional study was conducted in children (aged < 18 years) living at a rural sub-district in the north-eastern part of Bangladesh. Data were collected between May and June 2018 from children in households from randomly chosen villages of that sub-district. All children $<18$ years who resided in this rural community for the last six months were eligible for this study.

Injuries were categorized as major and minor based on how many days it hampered regular activities- as used in studies in Tanzania, Ghana, and Bangladesh. $(7,23,24)$ A minor injury was when regular activities were hampered less than 30 days and a major injury when regular activities were hampered 30 or more days. A minor injury must have occurred in the previous three months and a major injury in the previous one year because the recall time is longer for major injuries. ${ }^{(25)}$

The sample size of 1002 was calculated using the standard formula of $n=z^{2} p q / d^{2}$, with a prevalence of $0.12^{(21)}$ for injuries in general, the precision of 0.03 , design effect of two (2) for cluster sampling, and a response rate of $90 \%$. We purposively chose Belabo Sub-district under Narshingdi district because the health department of Bangladesh government was planning on starting a non-communicable disease surveillance at this sub-district which may include injuries and this project would provide baseline information for child injuries. The sub-district is around 80 kilometres northeast from Dhaka-the capital. In 2011, the sub-district contained eight unions, 100 villages, 42,377 households, and 73,086 children. ${ }^{(26)}$ On average, there were 424 households and 730 children per village with 1.72 children per household. For this study, each village was considered a cluster. A total of 25 villages were selected randomly and proportionally to the number of villages in each union at $25 \%$ from the eight unions. From every village, the starting point was the "Jame Mosque" which is the mosque where most people go to Friday prayers. From this mosque, a pen was spun to provide the direction to travel to select the households to be surveyed in the village. The team traveled in the direction of the pen and surveyed every household until 41 households were surveyed. From every household, one child was recruited. If more than one child resided in the house, one child was randomly selected for an interview. When no resident child lived in the house, the data collection team visited the next adjacent household in the same direction. If the child or family was not home, the data collection team revisited the household one more time. If the child still was not available during the second visit, we dropped the household and selected the household next to the last recruited one. With prior verbal assent of the child (>7 years) and informed written consent of the guardian, data were collected in a face-to-face interview with the mother using a pre-tested semi-structured questionnaire along with an observation checklist for the household environment. If the mother was not available, the father or another responsible adult or caregiver of the child was interviewed.

Data on the child's demography, socio-economic status of the family, and injury-related events of the selected child (injury type, duration of illness, injury-related deaths, injured parts of the body, place of occurrence of injury) were collected. For both categories, data on fall, cut, burn, transport, and other injuries (injury from a blunt object, animal source, near-drowning, electrocution, and other patterns) were recorded. Data collectors, with permission, conducted a walk-through survey around the household to fill up the observation checklist on environmental traits (presence of open water body within ten meters of a house, separate kitchen, fireplaces in open spaces, the position of sharp instruments, leaned ladders, type of power source of light, loose electric wires, dumping of garbage, and storage of medicine or insecticides). Though the study was focused on the non-fatal injury of alive children, data were additionally collected on the death event of any child of the household in the last one year and whether it was because of injury and if it was, regarding its pattern.

For analysis, children were classified into five age groups- infant (<1 year), 1-4 years, 5-9 years, 10-14 years, and 15-17 years; this classification was used in previous surveys. ${ }^{(21,22)}$ Prevalence and patterns were enumerated as proportions. Prevalence of minor injury was calculated as the proportion of minor injured children in the last three months and the prevalence of major injury was calculated as the proportion of majorly injured children in the last one year out of all interviewed children. An overall risk profile, including the socioeconomic and demographic status of the child and its household environment, for major and minor injury, was analyzed first. For further 
sub-analysis of both major and minor injuries, age-groups were considered as the basis. For revealing risk profiles, cross-tabulations, and bivariate analyses namely Chi-square test was done to assess for homogeneity, and Odds Ratio with $95 \%$ Confidence Interval (Cl) was calculated to measure the degree of association. STATA version 14.2 was used for data analysis.

\section{Results}

\section{Socio-demographic and environmental background}

A total of 1025 households were visited to meet the target sample size of 918 . There was a non-response rate of $9 \%$, ten households were empty, and six households did not have any child. Children were available in most households during interview time, as there was an ongoing vacation of schools due to the Ramadan. In $22 \%$ of households, there was a single child, which was recruited for the interview. The mother of the child was the respondent on $90 \%$ of occasions.

The mean age of 918 children in the survey was 8.0 years (SD 5.0) and most children (29\%) were in the 5-9-year age group. The children were nearly equally distributed in both genders. Excluding the children below 4 years of age, $70 \%$ (639/917) received some type of education. We found $20 \%$ of the mothers were uneducated; $77 \%$ of the mothers worked for more than five hours a day and $34 \%$ of the under 6 children remained unsupervised while their mother worked. The average monthly family income was 10001-20000 Bangladeshi Taka (BDT) for $60 \%$ of families and $72 \%$ of families had pet animals in their houses. (Table 1: Social and environmental characteristics of children (<18 years), Belabo sub-district, Narshingdi district, 2018). 
Social and environmental characteristics of children (<18 years), Belabo sub-district, Narshingdi district, 2018

\begin{tabular}{|c|c|c|c|}
\hline Characteristics & & Frequency & $\%$ \\
\hline \multicolumn{4}{|l|}{ Social characteristics } \\
\hline \multirow[t]{5}{*}{ Age of child (years) $(n=915)$} & Infant & 45 & 5 \\
\hline & $1-4$ & 235 & 26 \\
\hline & $5-9$ & 268 & 29 \\
\hline & $10-14$ & 249 & 27 \\
\hline & $15-17$ & 118 & 13 \\
\hline \multirow[t]{2}{*}{ Sex of child $(n=917)$} & Male & 459 & 50 \\
\hline & Female & 458 & 50 \\
\hline \multirow[t]{5}{*}{ Mother's age (years) $(n=900)$} & $15-24$ & 179 & 20 \\
\hline & $25-34$ & 423 & 47 \\
\hline & $35-44$ & 213 & 24 \\
\hline & $45-54$ & 80 & 9 \\
\hline & 55 and more & 5 & 1 \\
\hline \multirow{3}{*}{$\begin{array}{l}\text { Mothers' education* } \\
(n=912)\end{array}$} & Illiterate & 185 & 20 \\
\hline & Primary & 232 & 25 \\
\hline & Secondary and above & 495 & 54 \\
\hline \multirow[t]{3}{*}{ Mothers' working hours $(\mathrm{n}=905)$} & $1-4$ & 211 & 23 \\
\hline & $5-8$ & 653 & 72 \\
\hline & 9 and more & 41 & 5 \\
\hline \multirow[t]{6}{*}{ Supervision of < 6 child while mother's work $(n=318)$} & None & 108 & 34 \\
\hline & Father & 11 & 3 \\
\hline & Elder siblings & 27 & 8 \\
\hline & Grandparents & 136 & 43 \\
\hline & Any other member of family & 18 & 6 \\
\hline & Neighbors & 18 & 6 \\
\hline \multirow[t]{4}{*}{ Average monthly family income $(n=904)$} & 10000 and below & 235 & 26 \\
\hline & $10001-20000$ & 546 & 60 \\
\hline & $20001-30000$ & 108 & 12 \\
\hline & 30001 and more & 15 & 2 \\
\hline \multirow[t]{2}{*}{ Presence of pet animal at house $(n=918)$} & No & 257 & 28 \\
\hline & Yes & 661 & 72 \\
\hline \multicolumn{4}{|l|}{ Environmental characteristics } \\
\hline \multirow[t]{3}{*}{ Kitchen separated from rooms $(n=915)$} & Yes & 683 & 75 \\
\hline & No & 40 & 4 \\
\hline & Cooks inside room and in kitchen & 192 & 21 \\
\hline Fireplaces in open spaces other than kitchen $(n=911)$ & Yes & 47 & 5 \\
\hline
\end{tabular}




\begin{tabular}{|c|c|c|c|}
\hline \multicolumn{2}{|l|}{ Characteristics } & $\begin{array}{l}\text { Frequency } \\
864\end{array}$ & $\begin{array}{l}\% \\
95\end{array}$ \\
\hline & No & & \\
\hline \multirow[t]{3}{*}{ Position of sharp instruments in the house $(n=912)$} & Openly on the floor/ground & 809 & 89 \\
\hline & Openly within 2.5 feet from the ground & 34 & 4 \\
\hline & $\begin{array}{l}\text { In a covered box on floor or within } 2.5 \\
\text { feet }\end{array}$ & 69 & 8 \\
\hline \multirow{2}{*}{$\begin{array}{l}\text { Ladders kept leaned against walls or trees or heightened objects }(n= \\
913)\end{array}$} & Yes & 78 & 9 \\
\hline & No & 835 & 91 \\
\hline \multirow[t]{4}{*}{ Power source of light in the house $(n=914)$} & Electric source & 872 & 95 \\
\hline & Solar source & 1 & 0.11 \\
\hline & Both & 37 & 4 \\
\hline & Non-electric non-solar source & 4 & 0.44 \\
\hline \multirow[t]{2}{*}{ Dumping of garbage inside house or house premises $(n=912)$} & Yes & 515 & 56 \\
\hline & No & 397 & 44 \\
\hline
\end{tabular}

*mothers who received education from/related "madrasa" were considered illiterate as even introduction to the formal education were not usually delivered there.

In the environmental survey, $25 \%$ of houses had cooking facilities inside the living room and open fireplaces other than the kitchen were found in $5 \%$ of houses. Sharp instruments were placed in easily accessible places in $93 \%$ of instances. Most families (91\%) did not keep any ladder leaned against walls or trees or heightened objects. Only electricity was used in $95 \%$ of households and more than half of households (56\%) dumped garbage inside or on-premises.

\section{Injury morbidity and patterns}

The prevalence of major and minor injury-related morbidity was $2.4(95 \% \mathrm{Cl} 1.5-3.6)$ and $7.4(95 \% \mathrm{Cl} 5.8-9.3)$ respectively. (Fig. 1: Prevalence of major and minor injury in different child age-groups, Belabo sub-district, Narshingdi district, 2018) No injury was observed in infants. The highest morbidity was found in 5-9 and 1-4-year age group for major and minor injuries respectively Median (IQR) duration of illness was 35 days (30-75) for major injury and 7 days (4-15) for a minor injury.

Out of four deaths reported in a period of one year before conducting data collection, only one was due to fall injury and the dead child had a disability. As the mean number of children per household was found in this study to be 2.03 , the total number of children in all households were $1864(918 * 2.03=1863.54)$. So, the approximate prevalence of injury-related death in children in this community in the last year was $0.05 \%(95 \% \mathrm{Cl} 0.001-0.3)$.

Among different patterns of injuries, a history of falls was the most common for both major and minor injuries (Fig. 2: Patterns of major and minor injuries in children, Belabo sub-district, Narshingdi district, 2018). For major injuries $(n=22)$, falls caused major injuries in 5-9 and 10-14 year age groups only; cuts and burns in 1-4 year; and cuts and others (injury from a blunt object, animal source, neardrowning, electrocution, and other patterns) in 15-17 year age group. Unlike major injuries, falls were the commonest type of minor injury $(n=68)$, in all age groups; no transport injury and burn were observed in 1-4 year and 10-14-year age group respectively. Proportions of cuts and transport injuries were the same in all age groups except for 1-4 years. Only one case of near-drowning, which was a minor injury, was reported.

For both types of injury, limbs (lower followed by upper) were the most frequently affected part of the body. Lower limbs, upper limbs, and other parts of the body were injured in $50 \%, 36 \%$, and $4 \%$ cases of major injuries respectively. After a minor injury, lower limbs were affected in $40 \%$, upper limbs $26 \%$, head $21 \%$, and other parts in $13 \%$ of occasions. Home and home premises were the most common places for the occurrence of both major (59\%) and minor injuries (28\%). Roads were the second most frequent place, $27 \%$ for major and $22 \%$ for minor injuries. Injuries occurred at educational institutes in $9 \%$ of each of both types; and $5 \%$ major and $12 \%$ minor injuries took place at other places.

\section{The risk profile of child injury:}


The risk profile varied between major and minor injuries. (Table 2: Risk profile associated with major and minor child injury, Belabo subdistrict, Narshingdi district, 2018) For major injuries, male children were 4.6 (95\% Cl 1.5-18.9) times more at risk than female children. Also, when a child had a mother aged $\leq 30$ years or a mother working for $\geq 5$ hours a day or a family income of $<15000$ BDT or a pet animal at its house, he had higher ORs for having major injury compared to a child with a mother aged $>30$ years or a mother working $<5$ hours/day or a family income of $\geq 15000$ BDT or without pet animals respectively. However, none of these statistically significant. For a minor injury, children whose mothers worked for $\geq 5$ hours a day were $2.8(95 \% \mathrm{Cl} 1.2-7.2)$ times more at risk than those children with mothers working < 5 hours. Besides, a child aged $<6$ years who was supervised by at least someone during mothers' work had 3.2 ( $95 \%$ Cl 1.05-13) times more risk of getting a minor injury if compared to a similar child with no adult supervision. Male children and children with uneducated mothers also showed higher odds than female children and mothers with at least minimum education respectively, but not statistically justified. 
Table 2

Risk profile associated with major and minor child injury, Belabo sub-district, Narshingdi district, 2018

\begin{tabular}{|c|c|c|c|c|c|c|}
\hline \multirow[t]{2}{*}{ Risk profile } & \multicolumn{3}{|c|}{ Major injury } & \multicolumn{3}{|l|}{ Minor injury } \\
\hline & $\begin{array}{l}\text { Injured } \\
(n=22)\end{array}$ & $\begin{array}{l}\text { Un-injured (n } \\
=896)\end{array}$ & $\begin{array}{l}\text { OR } \\
(95 \% \\
\text { Cl) }\end{array}$ & $\begin{array}{l}\text { Injured }(n= \\
68)\end{array}$ & $\begin{array}{l}\text { Un-injured (n } \\
=850)\end{array}$ & $\begin{array}{l}\text { OR } \\
(95 \% \\
\mathrm{Cl})\end{array}$ \\
\hline \multicolumn{7}{|l|}{ Social risk group } \\
\hline \multirow[t]{2}{*}{ Male child } & $18(81.8)$ & $441(49.2)$ & 4.6 & $41(60.3)$ & $418(49.2)$ & 1.6 \\
\hline & & & $\begin{array}{l}(1.5- \\
18.9)\end{array}$ & & & $\begin{array}{l}(0.9- \\
2.7)\end{array}$ \\
\hline \multirow[t]{2}{*}{$\begin{array}{l}\text { At least some supervision of child }<6 \text { years } \\
\text { while mothers' work }\end{array}$} & $\begin{array}{l}4(57.1) \\
(n=7)\end{array}$ & $\begin{array}{l}205(66.1)(n \\
=310)\end{array}$ & & $\begin{array}{l}23(85.2) \\
(n=27)\end{array}$ & $\begin{array}{l}186(64.1)(n \\
=290)\end{array}$ & \\
\hline & & & $\begin{array}{l}(0.1- \\
4.7)\end{array}$ & & & $\begin{array}{l}(1.05- \\
13)\end{array}$ \\
\hline \multirow{2}{*}{ Mothers' working for $\geq 5$ hours } & $17(77.3)$ & $677(75.6)$ & 1.03 & $60(88.2)$ & $634(74.6)$ & 2.8 \\
\hline & & & $\begin{array}{l}(0.4- \\
3.6)\end{array}$ & & & (1.2- \\
\hline \multirow[t]{2}{*}{ Mother's age $\leq 30$ years } & $13(59.1)$ & $465(51.9)$ & 1.3 & $32(47.1)$ & $446(52.5)$ & 0.8 \\
\hline & & & $\begin{array}{l}(0.5- \\
3.4)\end{array}$ & & & $\begin{array}{l}(0.5- \\
1.4)\end{array}$ \\
\hline \multirow[t]{2}{*}{ Uneducated mother } & $2(9.1)$ & $183(20.4)$ & 0.4 & $18(26.5)$ & $167(19.6)$ & 1.5 \\
\hline & & & $\begin{array}{l}(0.04- \\
1.6)\end{array}$ & & & $\begin{array}{l}(0.8- \\
2.6)\end{array}$ \\
\hline \multirow[t]{2}{*}{ Family income $<15000$ BDT/month } & $17(77.3)$ & $558(62.3)$ & 2.5 & $37(54.4)$ & $538(63.3)$ & 0.7 \\
\hline & & & $\begin{array}{l}(0.8- \\
10.2)\end{array}$ & & & $\begin{array}{l}(0.4- \\
1.2)\end{array}$ \\
\hline \multirow[t]{2}{*}{ Presence of pet animal at house } & $18(81.8)$ & $643(75.6)$ & 1.8 & $49(72.1)$ & $612(72)$ & 1 \\
\hline & & & $\begin{array}{l}(0.6- \\
7.3)\end{array}$ & & & $\begin{array}{l}(0.6- \\
1.8)\end{array}$ \\
\hline \multicolumn{7}{|l|}{ Environmental risks } \\
\hline \multirow[t]{2}{*}{ Dumping of garbage nearby house } & $19(86.4)$ & $496(55.4)$ & 5.0 & $39(57.4)$ & $476(56)$ & 1.04 \\
\hline & & & $\begin{array}{l}(1.5- \\
26.7)\end{array}$ & & & $\begin{array}{l}(0.6- \\
1.8)\end{array}$ \\
\hline \multirow{2}{*}{$\begin{array}{l}\text { Use of non-electric power source exclusively or } \\
\text { as complementary }\end{array}$} & $4(18.2)$ & $38(4.2)$ & 5 & $1(1.5)$ & $41(4.8)$ & 0.3 \\
\hline & & & $\begin{array}{l}(1.2- \\
16.2)\end{array}$ & & & $\begin{array}{l}(0.01- \\
1.8)\end{array}$ \\
\hline \multirow[t]{2}{*}{ Fireplaces in open spaces } & $2(9.1)$ & $45(5)$ & 1.9 & $9(13.2)$ & $38(4.5)$ & 3.2 \\
\hline & & & $\begin{array}{l}(0.2- \\
8.1)\end{array}$ & & & $\begin{array}{l}(1.3- \\
7.2)\end{array}$ \\
\hline \multirow[t]{2}{*}{ Absence of a separate kitchen } & $6(27.3)$ & $226(25.2)$ & 1.1 & $15(22.1)$ & $217(25.5)$ & 0.8 \\
\hline & & & $(0.4-3)$ & & & $\begin{array}{l}(0.4- \\
1.5)\end{array}$ \\
\hline \multirow[t]{2}{*}{ Easily access to storage of sharp instruments } & $20(90.9)$ & $823(91.2)$ & 0.8 & 61 (89.7) & $782(92)$ & 0.8 \\
\hline & & & $\begin{array}{l}(0.2- \\
7.3)\end{array}$ & & & $\begin{array}{l}(0.3- \\
2.4)\end{array}$ \\
\hline \multirow[t]{2}{*}{ Leaned ladders } & 3 (13.6) & $75(8.4)$ & 1.7 & 8 (11.8) & $70(8.2)$ & 1.5 \\
\hline & & & $(0.3-6)$ & & & $\begin{array}{l}(0.6- \\
3.3)\end{array}$ \\
\hline
\end{tabular}


While analyzing environmental characteristics, using non-electric power source exclusively or as complementary by a household compared to electricity and dumping of garbage inside or near houses compared to non-dumping practices were $5.0(95 \% \mathrm{Cl} 1.2-16.2)$ and 5.0 (95\% $\mathrm{Cl} 1.5-26.7)$ times more related with the occurrence of major injury sequentially. Fireplaces in open spaces other than the kitchen and leaned ladders against heightened objects or trees were also found related, but not significant. The relation of sharp instruments, kept at easily than to a difficultly accessible place, to both major and minor injuries, though found protective for, was not statistically proved. If there was a fireplace in open spaces other than the kitchen, children had $3.2(95 \% \mathrm{Cl} 1.3-7.2)$ times more risk of having a minor injury.

The risk profile for minor injury in different age groups was also analyzed, which was found to vary among age groups. (Table 3: Risk profile associated with minor injury of different child age-group, Belabo sub-district, Narshingdi district, 2018) For 1-4 years, children whose mothers worked for $\geq 5$ hours a day ( $\mathrm{OR} 4.2,95 \% \mathrm{Cl} 1.2-22.4)$ and who were supervised by at least someone while mothers' works (OR 3.6, 95\% Cl 1.0-19.6) were identified as risk groups than children with mothers working $<5$ hours and children without adult supervision respectively. Male compared to female children, the presence of animals at the house, and open fireplaces other than kitchens were also found to have higher odds, though insignificant. Other social and environmental traits were protective, but none was statistically justified. Children of 5-9-year age were significantly at risk of minor injury if fireplaces were present in open spaces than in the kitchen (OR $5.7,95 \% \mathrm{Cl} 1.4-19.8)$. Other related risk characteristics for this age group were being a male child; having uneducated mothers, working $\geq$ 5 working hours by the mother; the presence of dumped garbage nearby; and in addition for children < 6 -year, having adult supervision during mothers' work, yet all without significance. Male children (OR 12.5, 95\% Cl 1.7-544.3), along with children of uneducated mothers (OR 4.4, 95\% Cl 1.1-20.9) had a significant risk in the 10-14-year age group than similar children with female gender and with mothers having at least minimum education correspondingly. Children of mothers who worked $\geq 5$ hours compared to the lesser duration of works, those having pet animals, unseparated kitchen from rooms, and leaned ladders against trees or heightened objects at the house, had higher, but insignificant, ORs of getting a minor injury. For 15-17-year children, a minor injury was related more to those children who had a mother aged $\leq 30$ years than older age, had uneducated mothers than one with minimum education, and had the presence of open fireplaces outside kitchen, leaned ladders, and dumped garbage in household premises, though all these lacked statistical support. 
Table 3

Risk profile associated with minor injury of different child age-group, Belabo sub-district, Narshingdi district, 2018

\begin{tabular}{|c|c|c|c|c|c|c|c|c|c|c|c|c|}
\hline \multirow[t]{2}{*}{ Risk profile } & \multicolumn{3}{|c|}{$1-4$ year } & \multicolumn{3}{|c|}{ 5-9 year } & \multicolumn{3}{|c|}{ 10-14 year } & \multicolumn{3}{|c|}{ 15-17 year } \\
\hline & $\begin{array}{l}\text { Injured } \\
(n= \\
24)\end{array}$ & $\begin{array}{l}\text { Un- } \\
\text { injured } \\
(n= \\
211)\end{array}$ & $\begin{array}{l}\text { OR } \\
(95 \% \\
\text { Cl) }\end{array}$ & $\begin{array}{l}\text { Injured } \\
(n= \\
22)\end{array}$ & $\begin{array}{l}\text { Un- } \\
\text { injured } \\
(n= \\
246)\end{array}$ & $\begin{array}{l}\text { OR } \\
(95 \% \\
\text { Cl) }\end{array}$ & $\begin{array}{l}\text { Injured } \\
(n= \\
11)\end{array}$ & $\begin{array}{l}\text { Un- } \\
\text { injured } \\
(n= \\
238)\end{array}$ & $\begin{array}{l}\text { OR } \\
\text { (95\% } \\
\text { Cl) }\end{array}$ & $\begin{array}{l}\text { Injured } \\
(n= \\
11)\end{array}$ & $\begin{array}{l}\text { Un- } \\
\text { injured } \\
(\mathrm{n}= \\
107)\end{array}$ & $\begin{array}{l}\text { OR } \\
\text { (95\% } \\
\text { Cl) }\end{array}$ \\
\hline \multicolumn{13}{|c|}{ Social risk group } \\
\hline Male Child & $\begin{array}{l}14 \\
(58.3)\end{array}$ & $\begin{array}{l}112 \\
(53.1)\end{array}$ & $\begin{array}{l}1.2 \\
(0.5- \\
3.2)\end{array}$ & $\begin{array}{l}12 \\
(54.5)\end{array}$ & $\begin{array}{l}122 \\
(49.5)\end{array}$ & $\begin{array}{l}1.2 \\
(0.5- \\
3.3)\end{array}$ & $\begin{array}{l}10 \\
(91)\end{array}$ & $\begin{array}{l}106 \\
(44.5)\end{array}$ & $\begin{array}{l}12.5 \\
(1.7- \\
544.3)\end{array}$ & $\begin{array}{l}5 \\
(45.5)\end{array}$ & $\begin{array}{l}55 \\
(51.4)\end{array}$ & $\begin{array}{l}0.8 \\
(0.2- \\
3.3)\end{array}$ \\
\hline $\begin{array}{l}\text { Uneducated } \\
\text { Mothers }\end{array}$ & $1(4.2)$ & $\begin{array}{l}23 \\
(10.9)\end{array}$ & $\begin{array}{l}0.4 \\
(0.01- \\
2.4)\end{array}$ & $\begin{array}{l}5 \\
(22.7)\end{array}$ & $\begin{array}{l}38 \\
(15.4)\end{array}$ & $\begin{array}{l}1.6 \\
(0.4- \\
4.9)\end{array}$ & $\begin{array}{l}7 \\
(63.6)\end{array}$ & $\begin{array}{l}67 \\
(28.2)\end{array}$ & $\begin{array}{l}4.4 \\
(1.1- \\
20.9)\end{array}$ & $\begin{array}{l}5 \\
(45.5)\end{array}$ & $\begin{array}{l}36 \\
(33.6)\end{array}$ & $\begin{array}{l}1.6 \\
(0.4- \\
6.7)\end{array}$ \\
\hline $\begin{array}{l}\text { Mothers } \\
\text { working for } \\
\geq 5 \text { hours }\end{array}$ & $\begin{array}{l}21 \\
(87.5)\end{array}$ & $\begin{array}{l}131 \\
(62.1)\end{array}$ & $\begin{array}{l}4.2 \\
(1.2- \\
22.4)\end{array}$ & $\begin{array}{l}18 \\
(81.8)\end{array}$ & $\begin{array}{l}195 \\
(79.3)\end{array}$ & $\begin{array}{l}1.5 \\
(0.4- \\
8.3)\end{array}$ & $\begin{array}{l}10 \\
(91)\end{array}$ & $\begin{array}{l}205 \\
(86.1)\end{array}$ & $\begin{array}{l}1.5 \\
(0.2- \\
67.7)\end{array}$ & $\begin{array}{l}11 \\
(100)\end{array}$ & $\begin{array}{l}81 \\
(75.7)\end{array}$ & - \\
\hline $\begin{array}{l}\text { At least } \\
\text { some } \\
\text { supervision } \\
\text { of child < } 6 \\
\text { years while } \\
\text { mothers' } \\
\text { work }\end{array}$ & $\begin{array}{l}21 \\
(87.5) \\
(n= \\
24)\end{array}$ & $\begin{array}{l}131 \\
(65.83) \\
(n= \\
199)\end{array}$ & $\begin{array}{l}3.6 \\
(1.03- \\
19.6)\end{array}$ & $\begin{array}{l}2 \\
(0.67) \\
(n=3)\end{array}$ & $\begin{array}{l}20 \\
(39.2) \\
(n= \\
51)\end{array}$ & $\begin{array}{l}3.1 \\
(0.1- \\
188.7)\end{array}$ & $\mathrm{N} / \mathrm{A}$ & $\mathrm{N} / \mathrm{A}$ & $\mathrm{N} / \mathrm{A}$ & $\mathrm{N} / \mathrm{A}$ & $\mathrm{N} / \mathrm{A}$ & $\mathrm{N} / \mathrm{A}$ \\
\hline $\begin{array}{l}\text { Mother's } \\
\text { age } \leq 30 \\
\text { years }\end{array}$ & $\begin{array}{l}18 \\
(75)\end{array}$ & $\begin{array}{l}189 \\
(89.6)\end{array}$ & $\begin{array}{l}0.5 \\
(0.1- \\
2.03)\end{array}$ & $\begin{array}{l}12 \\
(54.5)\end{array}$ & $\begin{array}{l}146 \\
(59.3)\end{array}$ & $\begin{array}{l}0.8 \\
(0.3- \\
2.2)\end{array}$ & $1(9.1)$ & $\begin{array}{l}59 \\
(24.8)\end{array}$ & $\begin{array}{l}0.3 \\
(0.01- \\
2.1)\end{array}$ & $1(9.1)$ & $7(6.5)$ & $\begin{array}{l}1.6 \\
(0.03- \\
14.6)\end{array}$ \\
\hline $\begin{array}{l}\text { Family } \\
\text { income < } \\
15000 \\
\text { BDT/month }\end{array}$ & $\begin{array}{l}15 \\
(0.63)\end{array}$ & $\begin{array}{l}143 \\
(67.8)\end{array}$ & $\begin{array}{l}0.7 \\
(0.3- \\
2.01)\end{array}$ & $\begin{array}{l}12 \\
(54.5)\end{array}$ & $\begin{array}{l}169 \\
(68.7)\end{array}$ & $\begin{array}{l}0.5 \\
(0.2- \\
1.4)\end{array}$ & $\begin{array}{l}6 \\
(54.5)\end{array}$ & $\begin{array}{l}141 \\
(59.2)\end{array}$ & $\begin{array}{l}0.8 \\
(0.2- \\
3.5)\end{array}$ & $\begin{array}{l}4 \\
(36.4)\end{array}$ & $\begin{array}{l}51 \\
(47.7)\end{array}$ & $\begin{array}{l}0.7 \\
(0.1- \\
3.2)\end{array}$ \\
\hline $\begin{array}{l}\text { Presence of } \\
\text { pet animal } \\
\text { at house }\end{array}$ & $\begin{array}{l}19 \\
(79.2)\end{array}$ & $\begin{array}{l}138 \\
(65.4)\end{array}$ & $\begin{array}{l}2.01 \\
(0.7- \\
7.2)\end{array}$ & $\begin{array}{l}12 \\
(54.5)\end{array}$ & $\begin{array}{l}176 \\
(71.5)\end{array}$ & $\begin{array}{l}0.5 \\
(0.2- \\
1.3)\end{array}$ & $\begin{array}{l}10 \\
(90.9)\end{array}$ & $\begin{array}{l}188 \\
(79)\end{array}$ & $\begin{array}{l}2.7 \\
(0.4- \\
117.7)\end{array}$ & $\begin{array}{l}8 \\
(72.7)\end{array}$ & $\begin{array}{l}87 \\
(81.3)\end{array}$ & $\begin{array}{l}0.6 \\
(0.1- \\
3.9)\end{array}$ \\
\hline \multicolumn{13}{|c|}{ Environmental risks } \\
\hline $\begin{array}{l}\text { Fireplaces } \\
\text { in open } \\
\text { spaces }\end{array}$ & $2(8.3)$ & $9(4.3)$ & $\begin{array}{l}2.02 \\
(0.2- \\
10.7)\end{array}$ & $\begin{array}{l}5 \\
(22.7)\end{array}$ & $\begin{array}{l}12 \\
(4.9)\end{array}$ & $\begin{array}{l}5.7 \\
(1.4- \\
19.8)\end{array}$ & 0 & $\begin{array}{l}10 \\
(4.2)\end{array}$ & - & $\begin{array}{l}2 \\
(18.2)\end{array}$ & $5(4.7)$ & $\begin{array}{l}4.4 \\
(0.4- \\
31.8)\end{array}$ \\
\hline $\begin{array}{l}\text { Leaned } \\
\text { ladders }\end{array}$ & $1(4.2)$ & $9(4.3)$ & $\begin{array}{l}1 \\
(0.02- \\
7.5)\end{array}$ & $1(4.5)$ & $\begin{array}{l}29 \\
(11.8)\end{array}$ & $\begin{array}{l}0.4 \\
(0.01- \\
2.4)\end{array}$ & $\begin{array}{l}3 \\
(27.3)\end{array}$ & $\begin{array}{l}21 \\
(8.8)\end{array}$ & $\begin{array}{l}3.9 \\
(0.6- \\
17.6)\end{array}$ & $\begin{array}{l}3 \\
(27.3)\end{array}$ & $\begin{array}{l}10 \\
(9.3)\end{array}$ & $\begin{array}{l}3.6 \\
(0.5- \\
18.2)\end{array}$ \\
\hline $\begin{array}{l}\text { Absence of } \\
\text { a separate } \\
\text { kitchen }\end{array}$ & $\begin{array}{l}4 \\
(16.7)\end{array}$ & $\begin{array}{l}54 \\
(25.6)\end{array}$ & $\begin{array}{l}0.6 \\
(0.1- \\
1.8)\end{array}$ & $\begin{array}{l}4 \\
(18.2)\end{array}$ & $\begin{array}{l}70 \\
(28.5)\end{array}$ & $\begin{array}{l}0.6 \\
(0.1- \\
1.8)\end{array}$ & $\begin{array}{l}5 \\
(45.5)\end{array}$ & $\begin{array}{l}45 \\
(18.9)\end{array}$ & $\begin{array}{l}3.6 \\
(0.8- \\
14.7)\end{array}$ & $\begin{array}{l}2 \\
(18.2)\end{array}$ & $\begin{array}{l}29 \\
(27.1)\end{array}$ & $\begin{array}{l}0.6 \\
(0.06- \\
3.1)\end{array}$ \\
\hline $\begin{array}{l}\text { Dumping of } \\
\text { garbage } \\
\text { nearby } \\
\text { house }\end{array}$ & $\begin{array}{l}11 \\
(45.8)\end{array}$ & $\begin{array}{l}116 \\
(55)\end{array}$ & $\begin{array}{l}0.7 \\
(0.3- \\
1.7)\end{array}$ & $\begin{array}{l}15 \\
(68.2)\end{array}$ & $\begin{array}{l}139 \\
(56.5)\end{array}$ & $\begin{array}{l}1.6 \\
(0.6- \\
4.9)\end{array}$ & $\begin{array}{l}6 \\
(54.5)\end{array}$ & $\begin{array}{l}139 \\
(58.4)\end{array}$ & $\begin{array}{l}0.8 \\
(0.2- \\
3.6)\end{array}$ & $\begin{array}{l}7 \\
(63.6)\end{array}$ & $\begin{array}{l}56 \\
(52.3)\end{array}$ & $\begin{array}{l}1.5 \\
(0.4- \\
7.5)\end{array}$ \\
\hline
\end{tabular}


In rural Bangladesh, non-fatal child injury, either major or minor, added considerable morbidity burden to non-communicable childhood illness; however, child injuries were preventable, and addressing the risk factors could help to reduce the number of injury events. There remained unavailability of recent information on the patterns and associated risks, particularly considering child age groups. This study presented with age group related variability in patterns with as well as the sociodemographic and environmental risks to child injury with an aim to aiding information for preventive measures, though identification of true risk factors was beyond its scope.

In this study, the observed prevalence of both the major and the minor injury was lower than before $(21,23,27,28)$ and variability was noted among age groups. However, this could not be considered a true reduction in burden. Because, for capturing minor injuries a shorter recall period of 'previous three months' was used in this study, and the contextual environment and study population were different for major injury, which might be the reason for the observed differences. Besides, both the prevalence might have changed due to changing socioeconomic, cultural, and educational backgrounds over the past ten years, still requiring intervention for further reduction. The highest affected age groups were different for major and minor injuries. Prevalence in infants could not be obtained as neither major nor minor injury was observed in them. This indicated a target group approach for preventive measures to be considered for these two categories of injury.

The prevalence of death as observed in this study was lower in figure compared to an earlier study (prevalence of injury deaths in the oneyear period was $0.096 \%, 95 \% \mathrm{Cl} 0.037 \%-0.199 \%$ ) ${ }^{(27)}$ and the nationwide survey in 2016 (prevalence of injury deaths in the two-year period was $0.13 \%, 95 \% \mathrm{Cl} 0.12 \%-0.14 \%)^{(21)}$. However, these studies were different from the present as per the inclusion of people of all ages and a longer recall period for that survey one. In fact, the observed prevalence indicated a higher frequency of injury-related child death from the previous considering contextual relevance, which demanded the intervention.

For both types of injury, fall was the most common pattern; cut, transport, and burn injuries were in queue accordingly. These patterns matched with previous nation-wide BHIS 2016 survey, which showed that falls, cuts, and burns were major patterns of injury in children aged < 18 years ${ }^{(21)}$; besides, fall was found as the leading pattern in other studies also. ${ }^{(13-15,20,29-31)}$ However, patterns varied widely while considering different age groups. For the major type, 1-4-year children were mostly injured by cuts and burns, 5-9 years and 10-14 years by falls, and 15-17 year by cuts and other injuries respectively. And for the minor type, though falls were the commonest pattern throughout all age groups, other patterns varied considerably among different age groups. Interestingly, in contrast to other studies, only one event of near-drowning was reported here. The probable reason might be that earlier studies focused on injury-mortality and drowning was the leading cause of 'fatal' injury $(21,22,29,32)$, whereas this study targeted non-fatal injuries. Hence, patterns of injury should be taken into account before the introduction of any injury intervention measures.

In this descriptive study, the variation in risk profile with injury type was also observed. However, sub-analysis was not conducted for children with major injuries as the total number of cases was only 22. Among different social characteristics, a major injury occurred significantly more in male children as similar to prior findings of male predominance in such injury ${ }^{(23)}$. The probable explanation might be related to the restlessness and risk-taking nature of a male child when compared to a female one. Henceforth, any preventive measure and ways of implementation should have a special emphasis on male sex.

For environmental traits, using non-electric power sources exclusively or as complementary and dumping garbage nearby households showed a significant risk for the occurrence of major injury. In a resource-inadequate country like Bangladesh, not all households had access to electricity, let alone an uninterrupted flow; and people were used to using alternate sources (kerosene lamp-like kupi, solar, candles, and others), though there was not enough lighting produced. The dim light, along with the source ${ }^{(33)}$ and careless handling, might be the reason for association with injury. As for dumping garbage, it was a common practice in rural Bangladesh to throw many household wastes nearby and dump garbage on the premises. Movement of children unaware of these might result in injuries, severe enough to cause a fracture or deep cut. However, as the environmental observational checklists were developed depending upon the Bangladesh Health and Injury Survey 2005 survey (qualitative section) considering environmental settings common to rural Bangladesh (22), relevant other studies were not available for comparison. And also, identifying the true risk factors was beyond the scope of a descriptive study; and thereby case-control study along with a qualitative part was recommended for further evaluation.

While analyzing social risks for minor injury, children whose mothers worked for $\geq 5$ hours and children $<6$ years who had at least some supervision during mothers' work were significantly more at risk of being injured. This was especially observed for 1-4-year children when the analysis was done considering age groups. The probable explanation could be that mothers who worked for longer hours, kept their children under the supervision of others, and then lack of closer supervision resulted in injury to those children. In fact, the absence of closer supervision was a risk factor for the occurrence of child injury as observed in previous literature. $(15,18,34,35)$ Considering that 
children were having injuries in presence of supervisors, caregivers of children could be provided with training on supervision and caring applications to reduce the home-based risks.

For the 10-14-year age group, male children and children of uneducated mothers were found to be at risk of minor injury out of all features. The similarity of social risk groups was found in other literature, however, irrespective of injury categorization $(4,13,15,27)$ and age-groups. $(4,7,13,16,17,28,36,37)$ Henceforth, education should be promoted for all, and male predominance should be considered while designing an intervention.

Of different environmental characteristics, fireplaces in open space were found to be more significantly related to a minor injury, particularly for 5-9-year children. Making fireplaces in open space was usual in rural areas, especially in winter, for processing rice from the grain and for cooking at times of occasions. ${ }^{(22)}$ Children being unaware of these fireplaces or its remnants usually got injured. Studies were found showing the relation of injuries with active fire, fireworks, or firecrackers. $(20,37,38)$ Therefore, injury prevention programmes should also direct at creating awareness in rural people about child-care while using open fireplaces and proper management of remnants to avoid injury.

Varying degrees of an insignificant relationship was observed between minor type injury in different age groups of children and different known environmental risk factors. $(4,22)$ This might be due to the dissimilar analysis approach used in this study, where age groups were considered. However, an in-depth study was needed to find out the actual scenario.

The findings in this study were limited by focusing on an age-group related style in a cross-sectional study, which could not establish a significant relationship of injury even with known risks, which might produce a good result for a case-control study. Also, analysis of risk profile could not be done for major injuries in the same way as such events were smaller in number. The latter might be due to the methods of categorization of injury, where minor ones might include some actually severe injuries. Besides, as data were collected from only one Upazila (sub-district), the results were not generalizable to all children of Bangladesh.

\section{Conclusion}

Injury is a growing problem in our country; child injury requiring particular attention, as many of these injuries are preventable if proper measures can be adopted. For this purpose, proper identification of risk profile along with the injury patterns and activities prior to the event is required. In this study, total and age group related burden and patterns of child injury considering the severity in the form of longer or shorter disability days in a Bangladeshi rural community were elicited. Besides, social risk groups and environmental risk factors as related to different age groups were also identified. However, risk characteristics were not well established in a cross-sectional study. Hence, further case-control study is recommended for a better understanding of the relation of varying injury risk profiles with injury severity and variable age groups, which in the future can guide policy formulation for child injury prevention.

\section{Declarations}

Ethics approval and consent to participate: The ethical approval of the study was taken from the Institutional Review board of Institute of Epidemiology, Disease Control and Research (IEDCR), the reference number being IEDCR/IRB/2018/04, dated 23/04/2018. Prior to data collection verbal assent of the child (>7 years) and informed written consent of the guardian was ensured.

Consent for publication: Not applicable

Availability of data and material: The dataset supporting the conclusions of this article is included within the article as its additional file (Additional file 1).

Competing interests: The authors declare that they have no competing interests.

Funding: The study has been funded by the US-CDC through TEPHINET for the fellows in the FETP,B programme.

Disclosure statement: The author declares no conflict of interest. The views expressed in this article are those of the authors and do not necessarily represent the decisions, policy, or views of the US-CDC or TEPHINET or IEDCR.

Authors' contributions: NA wrote the study protocol, supervised data collection, analyzed and interpreted data and drafted the manuscript. MMB contributed significantly to the overall study, guiding data analysis and scientific writing. MSF was a contributor to the study protocol and scientific writing. All authors read and approved the final manuscript.

Page 12/16 
Acknowledgements: We express our gratitude to Dr. Alden Henderson, CDC, Atlanta, USA for his kind support in preparing this document. We also acknowledge the support of IEDCR, and Field Epidemiology Training Program of Bangladesh (FETP,B).

\section{References}

1. WHO. Injuries and Violence the Facts 2014. publication. http://www.who.int/violence_injury_prevention/en/ (as accessed on 22-112016).

2. WHO. Preventing injuries and violence: A guide for ministries of health. publication. Switzerland: Geneva; 2007. http://apps.who.int/iris/bitstream/10665/43628/1/9789241595254_eng.pdf. (as accessed on 22-11-2016).

3. Haagsma JA, Graetz N, Bolliger I, Naghavi M, Higashi H, Mullany EC, et al. The global burden of injury: incidence, mortality, disabilityadjusted life years and time trends from the Global Burden of Disease study 2013. Inj Prev. 2016;22(1):3-18.

4. Peden M. World report on child injury prevention: World Health Organization; 2008. http://www.emonline.com/download/medical_article/37295_world\%20report\%20on\%20child\%20injury.pdf (as accessed on 22-11-2016).

5. UNICEF. A league table of child deaths by injury in rich nations. Florence: Unicef Innocenti Research Center; 2001.

6. E. P. Childhood injuries in the European Union: can epidemiology contribute to their control. Acta Paediatr 2000;89(10):1244-9.

7. Moshiro C, Heuch I, Astrom AN, Setel P, Hemed Y, Kvale G. Injury morbidity in an urban and a rural area in Tanzania: an epidemiological survey. BMC Public Health. 2005;5:11.

8. Jiang X, Li D, Boyce W, Pickett W. Variations in injury among Canadian adolescents by urban-rural geographic status. Chronic Dis Can. 2007;28(1-2):56-62.

9. Hu G, Baker SP, Baker TD. Urban-rural disparities in injury mortality in China, 2006. The Journal of rural health: official journal of the American Rural Health Association and the National Rural Health Care Association. 2010;26(1):73 - 7.

10. Coben JH, Tiesman HM, Bossarte RM, Furbee PM. Rural-urban differences in injury hospitalizations in the U.S., 2004. American journal of preventive medicine. 2009;36(1):49-55.

11. Kim K, Ozegovic D, Voaklander DC. Differences in incidence of injury between rural and urban children in Canada and the USA: a systematic review. Injury prevention: journal of the International Society for Child Adolescent Injury Prevention. 2012;18(4):264-71.

12. Abdalla S, Ahmed S, Swareldahab Z, Bhalla K. Estimating the burden of injury in urban and rural Sudan in 2008. Injury prevention: journal of the International Society for Child and Adolescent Injury Prevention; 2016.

13. Atak N, Karaoglu L, Korkmaz Y, Usubutun S. A household survey: unintentional injury frequency and related factors among children under five years in Malatya. Turk J Pediatr. 2010;52(3):285-93.

14. He S, Lunnen JC, Puvanachandra P, Amar S, Zia N, Hyder AA. Global childhood unintentional injury study: multisite surveillance data. American journal of public health. 2014;104(3):e79-84.

15. Chaveepojnkamjorn W, Pichainarong N, Pooltawee S. Unintentional injuries among children aged 1-4 years at home. Southeast Asian J Trop Med Public Health. 2002;33(3):642-6.

16. CDC Child injury report. CDC,USA; 2008. https://www.cdc.gov/safechild/child_injury_data.html (as accessed on 18-06-2017).

17. Hijar-Medina MC, Tapia-Yanes R, Lopez-Lopez MV, Lozano-Ascencio R. [Mother's work and severity of accidental injuries in children]. Salud Publica Mex. 1995;37(3):197-204.

18. Schnitzer PG, Dowd MD, Kruse RL, Morrongiello BA. Supervision and risk of unintentional injury in young children. Injury prevention: journal of the International Society for Child Adolescent Injury Prevention. 2015;21(e1):e63-70.

19. Towner E, Therese D, Errington G, Burkes M, Towner J. Injuries in children aged 0-14 years and inequalities. London: Health Development Agency; 2005.

20. Bhuvaneswari N, Prasuna JG, Goel MK, Rasania SK. An epidemiological study on home injuries among children of 0-14 years in South Delhi. Indian J Public Health. 2018;62(1):4-9.

21. Bangladesh health and injury survey. 2016, summary report. Dhaka, Bangladesh: DGHS of MoHFW, CIPRB; 2016.

22. Bangladesh Health and Injury Survey. Report on children. Bangladesh: DGHS MoHFW, ICMH Dhaka, UNICEF, TASC;: Dhaka; 2005.

23. Kamal S. Serious Injury and Injurious Burden in Urban Bangladesh. Journal of Applied Science Technology. 2010;7(2):71-9.

24. Mock CNAF, Cummings P, Koepsell TD. Incidence and outcome of injury in Ghana: a community-based survey. Bull World Health Organ. 1999;77:955-64.

25. Moshiro C, Heuch I, Åstrøm AN, Setel P, Kvåle G. Effect of recall on estimation of non-fatal injury rates: a community based study in Tanzania. Inj Prev. 2005;11(1):48-52. 
26. District Statistics 2011, Narshingdi. Dhaka, Bangladesh: Bangladesh Bureau of Statistics (BBS); 2013.123 p.

27. Chowdhury SH, Karim MN, Rahman MR, Faiz MA, Ahmed F, Selim S. An epidemiological study of injury in a rural community in Bangladesh. Bangladesh Med Res Counc Bull. 2015;41(1):46-51.

28. Parmeswaran GG, Kalaivani M, Gupta SK, Goswami AK, Nongkynrih B. Unintentional Childhood Injuries in Urban Delhi: A CommunityBased Study. Indian journal of community medicine: official publication of Indian Association of Preventive Social Medicine. 2017;42(1):8-12.

29. Alonge O, Agrawal P, Talab A, Rahman QS, Rahman AF, El Arifeen S, et al. Fatal and non-fatal injury outcomes: results from a purposively sampled census of seven rural subdistricts in Bangladesh. The Lancet Global Health. 2017;5(8):e818-e27.

30. Chowdhury SM, Rahman A, Mashreky SR, Giashuddin SM, Svanstrom L, Horte LG, et al. The horizon of unintentional injuries among children in low-income setting: an overview from Bangladesh Health and Injury Survey. Journal of environmental public health. 2009;2009:435403.

31. Bhamkar R, Seth B, Setia MS. Profile and Risk Factor Analysis of Unintentional Injuries in Children. Indian J Pediatr. 2016;83(10):1114-20.

32. Jagnoor J, Bassani DG, Keay L, Ivers RQ, Thakur JS, Gururaj G, et al. Unintentional injury deaths among children younger than 5 years of age in India: a nationally representative study. Injury prevention: journal of the International Society for Child Adolescent Injury Prevention. 2011;17(3):151-5.

33. Mashreky SR, Rahman A, Khan TF, Svanstrom L, Rahman F. Determinants of childhood burns in rural Bangladesh: A nested casecontrol study. Health Policy. 2010;96(3):226-30.

34. Morrongiello BA, Corbett M, McCourt M, Johnston N. Understanding unintentional injury risk in young children II. The contribution of caregiver supervision, child attributes, and parent attributes. J Pediatr Psychol. 2006;31(6):540-51.

35. Morrongiello BA, Corbett M, McCourt M, Johnston N. Understanding unintentional injury-risk in young children I. The nature and scope of caregiver supervision of children at home. J Pediatr Psychol. 2006;31(6):529-39.

36. Chowdhury S, Rahman A, Mashreky SR, Giashuddin S, Svanström L, Hörte L, et al. The horizon of unintentional injuries among children in low-income setting: an overview from Bangladesh Health and Injury Survey. Journal of environmental and public health. 2009;2009.

37. Deng FM, Gong XM, Cui HY, Yang YJ, Hu PC. [Risk factors for unintentional injury among children in rural areas of Liling, Hunan Province, China]. Zhongguo Dang Dai Er Ke Za Zhi. 2014;16(5):524-8.

38. Nawroz Afreen AFR, Pierre Claquin, Sabine Chai and Meerjady Sabrina Flora. Current burn patterns in a rural community of Bangladesh: findings from surveillance data of January-June 2015. Safety 2018 abstracts; Bangkok, Thailand: Journal of Injury Prevention; 2018. p. A233.3-A4.

\section{Figures}




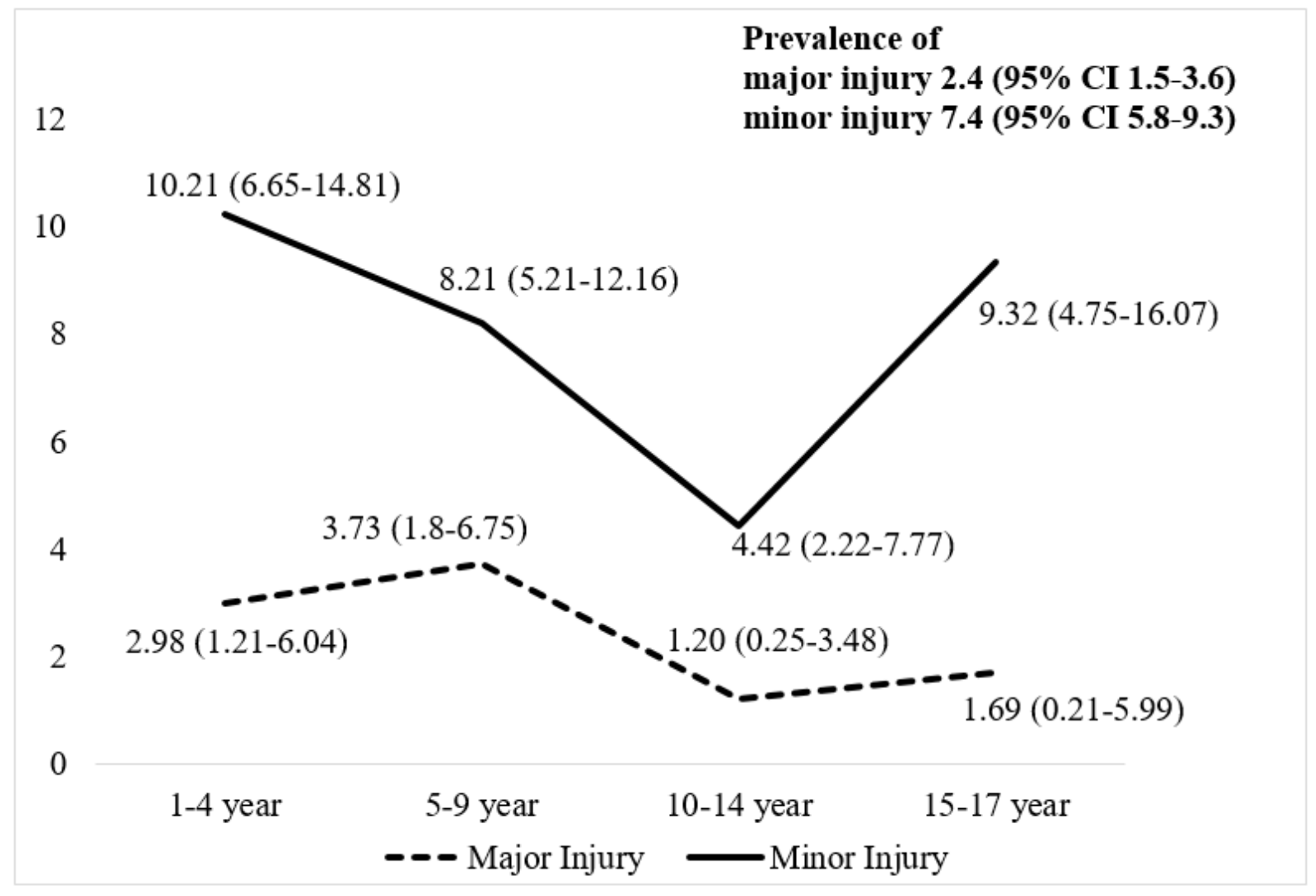

Figure 1

Prevalence of major and minor injury in different child age-groups, Belabo sub-district, Narshingdi district, 2018 

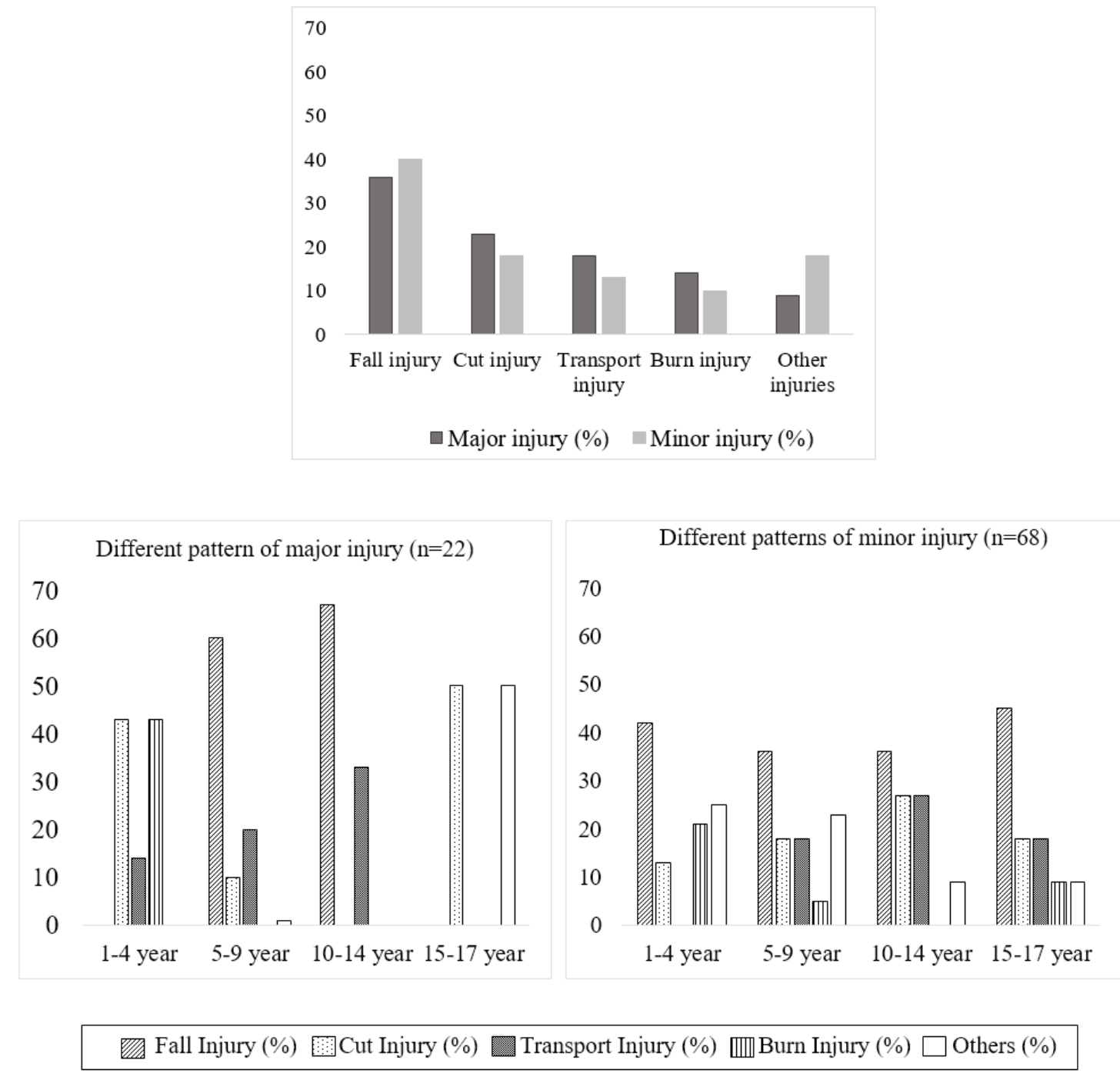

Figure 2

Patterns of major and minor injuries in children, Belabo sub-district, Narshingdi district, 2018

\section{Supplementary Files}

This is a list of supplementary files associated with this preprint. Click to download.

- Additionalfile1.Manuscriptdataset.dta 